\title{
Health of a Punjabi ethnic minority in Glasgow: a comparison with the general population
}

\author{
Rory Williams, Raj Bhopal, Kate Hunt
}

\begin{abstract}
Objective-To compare common health experiences of a South Asian (predominantly Punjabi) population with that of the general population, according to sex, and to relate patterns of health in the fourth decade of life to the pattern of hospital admission and mortality documented in the published reports.
\end{abstract}

Design and setting-A cross sectional survey with interviews and physical measures was undertaken in a two stage stratified random cluster sample in the city of Glasgow.

Sample-This comprised 159 South Asians aged $30-40$ years, mean age $35(73 \cdot 6 \%$ of those invited) and 319 subjects from the general population, all aged 35 years.

Measurements and main results-Body structure, lung function, pulse and blood pressure, history of physical and mental health, results of standardised questionnaires on mental health, angina and respiratory health, recent and past symptoms, history of accidents, and sickness behaviour were determined. South Asians were shorter, broader, and more overweight (women); they had lower values for forced expiratory volume in 1 second $\left(F E V_{1}\right)$ and forced vital capacity (FVC), a faster pulse, and higher diastolic pressure (men). Fewer South Asians had had accidents or digestive symptoms (men); more had psychosomatic and high total symptoms (women); fewer wore glasses, had lost teeth, or had long standing illness (men) (all $\mathbf{p}<0 \cdot 01)$. Women had a lower $\mathrm{FEV}_{1} / \mathrm{FVC}$ ratio $(\mathrm{p}<0.05)$.

Conclusions-South Asians were consistently disadvantaged only in terms of anthropometric measures. Otherwise, the many differences were balanced, with disadvantage being concentrated only among South Asian women. The health gap between sexes in South Asians seems higher than in the general population. The findings show patterns of health in the fourth decade of life which are consistent with patterns of hospital admission and mortality documented in the published reports.

f Lidemiol Community Health 1993; 47: 96-102

Britons with origins in the Indian subcontinent (hereafter called South Asians) comprise about $2 \cdot 4 \%$ of the British population ${ }^{1}$ and are culturally extremely heterogeneous. ${ }^{23}$ Their health is of particular interest for two main reasons. Firstly, their health care needs are different from those of the general population because of differences in their patterns of illness, concepts of health, lifestyle, and mode of communication, though these differences may be exaggerated or wrongly attributed to ethnic factors. ${ }^{4-6}$ Secondly, the finding and subsequent explanation of differences in their disease patterns may enhance understanding of aetiology. 48

Epidemiological studies of mortality ${ }^{8-10}$ and morbidity ${ }^{11}$ have shown important variations in the disease experience of South Asians, including by sex. The epidemiological focus has been on diseases that are either commoner or perceived as being commoner in this community 4512 -for example tuberculosis, ${ }^{13}$ rickets, ${ }^{14}$ diabetes, ${ }^{15}$ heart disease, ${ }^{16}$ and psychiatric disorders. ${ }^{17}$ Research on the underlying explanations for disease variations has, to date, focused on a few of these disease, for example rickets ${ }^{14}$ and heart disease. ${ }^{16}$ Emphasis on these diseases may have contributed to a perception that the health care needs of South Asians are greater and their health poorer than those of the general population; but without a broader spectrum of health measurements this has not been easy to show.

National surveys on lifestyle and health ${ }^{18}$ have met major problems that make it difficult to achieve high quality, reliable information on ethnic minorities. The numbers from each ethnic minority in random population samples are small; the average age is often much lower than in the general population; it is much easier to find those who live in areas where the minority is concentrated than those who are scattered elsewhere ${ }^{19}$; and there are technical problems of collecting valid information where there are linguistic and cultural differences. Thus, information on lifestyles and risk factors for disease has been derived mostly from surveys in areas in which ethnic minorities are concentrated, and usually relates to a narrow range of topics.

The Medical Sociology Unit of the Medical Research Council has been undertaking detailed, population based, cross sectional and cohort studies of lifestyle and health in the West of Scotland (The West of Scotland Twenty-07 Study). One subsample was of South Asian men and women, predominantly Punjabis, in their fourth decade, during the mid-life period that often shows major inequalities in the health of ethnic minorities. ${ }^{20}$ The South Asian subsample comprised approximately equal numbers of Muslims and non-Muslims, reflecting national proportions in Britain, and was statistically weighted to represent both concentrated and scattered members of the South Asian community in Glasgow. The questions addressed in this overview of the health data are: (1) how does the 
Glasgow South Asian community compare with the Glasgow population in general in a broad spectrum of measures reflecting common health experience? (2) are there differences in disadvantage by sex? and (3) how do patterns of health at age 30-40 years compare with the known pattern of hospital admissions and mortality?

\section{Methods}

SAMPLING

Fifty two postcode sectors, 22 of which were in Glasgow, were selected as a basis for the range of studies in a two stage, stratified random cluster sample from the Central Clydeside Conurbation. The general population sample used here was randomly sampled from those recorded as age 35 years on Strathclyde Regional Council's enhanced electoral register in 1987 . Of the 1688 originally approached by Strathclyde Regional Council, a total of 1096 people (65\%) provided written consent to have their names and addresses passed on to the Medical Research Council, and 985 $(89.9 \%)$ were subsequently interviewed. Of these, 319 lived in the 22 postcode sectors in Glasgow and supplied the health and physical measures used in this study.

With regard to the South Asian sample, 1981 census data showed that $97 \%$ of all the South Asians resident in the 22 Glasgow postcode sectors lived in 11 of them, and sampling was confined to these sectors. As described elsewhere, ${ }^{19}$ these 11 postcode sectors underrepresented Glasgow postcode sectors where only $0-2 \%$ of the population were South Asians. To remedy this, in those of the 11 postcode sectors which did have $0-2 \%$ South Asians the sampling fraction for individuals was raised, and the resultant data were also weighted statistically to represent population proportions by density.

The electoral rolls (1986) for the postcode sectors were scanned for South Asian first and second names. To identify households of nonelectors, the valuation roll for April 1987 was scanned and names that did not appear on the electoral roll were added to the list. This list of names was stratified on the basis of names into two categories, Muslim and non-Muslim, and approximately equal numbers of households from each category were sampled. The homes of 1439 South Asians aged 18 and over were now visited for a screening interview in which the age and sex of each person in the household was ascertained (response rate of $81.0 \%$ ). Where available, one person aged $30-40$ years was invited to participate from each household, selected randomly where there was more than one (the data then being reweighted statistically to represent the number available). Of 216 people invited to participate in the study, 173 agreed (response rate of $80.5 \%$ ), 159 of whom supplied the extended health and physical measurements reported here. The mean age of participants was 35 years.

\section{DATA COLLECTION}

Data were collected at two interviews in respondent's homes. The first interview was conducted by trained social survey interviewers and the second by nurses trained specifically in taking the physical measurements required. In the South
Asian sample, where the respondent's first language was not English, the bilingual interviewer previously assigned interpreted for the nurse; otherwise the nurse conducted the second interview as well as taking the physical measurements.

\section{INTERVIEW DATA}

Questionnaires focused on a wide range of health states and health problems commonly experienced by people in their 30s; and within the limitation of excluding events which are relatively rare at that age, an attempt was also made to select measures relevant to common causes of death. Thus, information was collected on current and past health, physical measures of health, perceived health, health beliefs, health care, medications, and health related lifestyle factors including smoking, drinking and diet, stress, and other aspects of mental health. The Rose angina questionnaire, ${ }^{21}$ the MRC chronic bronchitis questionnaire, ${ }^{22}$ and the 12 item general health questionnaire (GHQ) were used. ${ }^{23}$ Two scales of tendency to and recent experience of psychosomatic symptoms were developed from that used by Dressler, ${ }^{24}$ with Cronbach's alpha (a measure of unidimensionality) ranging from 0.71 to 0.78 , the higher values being for South Asians. The symptoms concerned were headache, difficulty sleeping, sweating a lot, 'nerves', muscular tension, always feeling tired, difficulty concentrating, palpitations or breathlessness, worrying over every little thing, indigestion or stomach trouble, faints or dizziness, and trembling hands. Additionally, details of origins, education, occupation, housing, household organisation, child rearing, family support and religion were collected. These questionnaires were adapted for the South Asian sample study by adding questions that were of specific interest in this group, for example experience of discrimination, diet, use of traditional healers, etc. The questionnaires were translated from English into Urdu, Hindi, and Punjabi by an educational psychologist fluent in all four languages (the latter three being closely related). The quality of the translation was tested by the translator and another polylingual interviewer piloting the schedules, and by further discussion with a bilingual doctor and other bilingual interviewers who covered all the languages concerned.

Interviewers for the South Asian sample were all literate in English and in at least one of the three South Asian languages concerned, and were given a week's interview training and a further week's close individual supervision. All scripts were checked for completeness and consistency by the scientists in charge, in nearly all cases within 48 hours of the interview. Doubtful or defective data were corrected by further contact with the respondent wherever possible.

\section{PHYSICAL MEASURES}

Height was measured using Nivotoise stadiometers, weight (clothed, without shoes) by portable electronic scales calibrated at the local trading standards office. The body mass index was calculated as weight $(\mathrm{kg})$ over height $\left(\mathrm{m}^{2}\right)$, and the categories of under- and overweight used follow the criteria of the Royal College of Physicians. ${ }^{25}$ Circumferences of hip (at the top of the iliac crest) and waist (at the midpoint between hip and ribs) 
were recorded clothed to the nearest centimetre. The pulse was taken as beats over 15 seconds, multiplied by four. Blood pressure was measured with a Hawkesley random zero sphygmomanometer with the subject in a sitting position and after five minutes of rest. An adult size cuff (with inflatable bladder $35 \times 12 \mathrm{~cm}$ ) was used in all cases. Readings were taken to the nearest even number and systolic and diastolic phase 5 were recorded. The reported results are the means of two readings. The measurements of one nurse were judged unreliable and her four subjects were excluded from the relevant analyses. There was one outlying record of high blood pressure in the South Asian sample, but other evidence suggests it was accurate, and its inclusion does not affect the significance of the results given below. Forced expiratory volume in one second $\left(\mathrm{FEV}_{1}\right)$ and forced vital capacity (FVC) were measured with a standard portable spirometer, and the highest of three readings is reported, standardised as $\mathrm{cl}$ over height in $\mathrm{m}^{3}{ }^{26}$ There was no significant correlation with weight after this was done.

\section{WEIGHTING}

Statistical correction was made for various biases in the South Asian sample, including undersampling of postcode sectors with few South Asians, and undersampling of those aged 30-40 years in households which had more than one such member. A fuller account of these procedures is available elsewhere. ${ }^{19}$ The greater sampling error implied has been calculated and allowed for in the significance levels reported. The weighting preserved the equally balanced strata of Muslims and non-Muslims, thus reflecting the national situ-

Table I Overall physical development at age 30-40 years in South Asians compared with general population in Glasgow, by sex

\begin{tabular}{|c|c|c|c|c|c|c|}
\hline \multirow[b]{2}{*}{$\begin{array}{l}\text { Physical } \\
\text { development }\end{array}$} & \multicolumn{2}{|l|}{ Men } & \multicolumn{2}{|l|}{ Women } & \multicolumn{2}{|l|}{ All } \\
\hline & $\begin{array}{l}\text { General } \\
\text { population }\end{array}$ & $\begin{array}{l}\text { South } \\
\text { Asians }\end{array}$ & $\begin{array}{l}\text { General } \\
\text { population }\end{array}$ & $\begin{array}{l}\text { South } \\
\text { Asians }\end{array}$ & $\begin{array}{l}\text { General } \\
\text { population }\end{array}$ & $\begin{array}{l}\text { South } \\
\text { Asians }\end{array}$ \\
\hline \multicolumn{7}{|l|}{ Body structure } \\
\hline $\begin{array}{l}\text { Height (mean, cm) } \\
\text { (SD) }\end{array}$ & $174 \cdot 1$ & $171 \cdot 1^{\star \star}$ & $159 \cdot 2$ & $154 \cdot 7^{\star \star \star}$ & $165 \cdot 8$ & $163 \cdot 1^{*}$ \\
\hline $\begin{array}{l}\text { (SD) } \\
\text { Weight (mean, kg) }\end{array}$ & $7 \cdot 3$ & $5 \cdot 6$ & $6 \cdot 0$ & $5 \cdot 6$ & $9 \cdot 9$ & $9 \cdot 9$ \\
\hline $\begin{array}{l}\text { Weight (mean, kg) } \\
\text { (SD) }\end{array}$ & $76 \cdot 6$ & $74 \cdot 4$ & $62 \cdot 7$ & $64 \cdot 6$ & $68 \cdot 8$ & $69 \cdot 6$ \\
\hline $\begin{array}{l}(\mathrm{SD}) \\
\text { Body mass index }\end{array}$ & $14 \cdot 1$ & $10 \cdot 7$ & $13 \cdot 5$ & $15 \cdot 3$ & $15 \cdot 4$ & $14 \cdot 0$ \\
\hline \multicolumn{6}{|l|}{ Body mass index } & \\
\hline (SD) & $4 \cdot 6$ & $3 \cdot 8$ & $5 \cdot 3$ & $6 \cdot 3$ & $5 \cdot 0$ & $\begin{array}{c}20 \cdot 2 \\
5 \cdot 2\end{array}$ \\
\hline Waist (mean, cm) & $88 \cdot 4$ & $92 \cdot 9^{\star \star}$ & $76 \cdot 5$ & $83 \cdot 1^{\star \star \star}$ & $81 \cdot 7$ & $88 \cdot 2^{\star \star \star}$ \\
\hline (SD) & $8 \cdot 9$ & $9 \cdot 8$ & 11.5 & $10 \cdot 8$ & $12 \cdot 0$ & $11 \cdot 4$ \\
\hline Hip (mean, cm) & $93 \cdot 1$ & $98 \cdot 3^{\star \star \star}$ & $93 \cdot 2$ & $98 \cdot 6^{\star \star}$ & $93 \cdot 1$ & $98 \cdot 4^{\star \star \star}$ \\
\hline (SD) & $8 \cdot 2$ & $7 \cdot 2$ & $11 \cdot 7$ & $10 \cdot 6$ & $10 \cdot 3$ & $9 \cdot 0$ \\
\hline \multicolumn{7}{|l|}{ Wast/hip ration } \\
\hline $\begin{array}{l}\text { (mean) } \\
(\mathrm{SD})\end{array}$ & $\begin{array}{l}.95 \\
.05\end{array}$ & $\begin{array}{l}.94 \\
.05\end{array}$ & $\begin{array}{l}\cdot 82 \\
.05\end{array}$ & $\begin{array}{l}\cdot 84^{\star \star} \\
\cdot 06^{-1}\end{array}$ & $\begin{array}{l}\cdot 88 \\
.08\end{array}$ & $\begin{array}{l}.90^{\star} \\
.07\end{array}$ \\
\hline \multirow{2}{*}{\multicolumn{7}{|c|}{$\begin{array}{l}\text { Lung Function } \\
\mathrm{FEV}_{1} / \text { height }^{3}\end{array}$}} \\
\hline & & & & & & \\
\hline (mean, $\mathrm{cl} / \mathrm{m}^{3}$ ) & $68 \cdot 0$ & $52 \cdot 6^{\star \star \star}$ & $63 \cdot 7$ & $49 \cdot 5^{\star \star \star}$ & $65 \cdot 6$ & $51 \cdot 1^{\star \star \star}$ \\
\hline $\begin{array}{l}\text { (SD) } \\
\text { FVC/height }^{3}\end{array}$ & $11 \cdot 8$ & $10 \cdot 9$ & $11 \cdot 1$ & $13 \cdot 0$ & $11 \cdot 6$ & $12 \cdot 0$ \\
\hline \multicolumn{7}{|l|}{ FVC/height ${ }^{3}$} \\
\hline $\begin{array}{l}\text { (mean, cl/m } \text { m }^{3} \\
\text { (SD) }\end{array}$ & $\begin{array}{l}83 \cdot 1 \\
12 \cdot 2\end{array}$ & $\begin{array}{l}63 \cdot 7^{\star \star \star} \\
11 \cdot 6\end{array}$ & $\begin{array}{l}77 \cdot 5 \\
11 \cdot 7\end{array}$ & $\begin{array}{l}61 \cdot 6^{\star \star \star} \\
11 \cdot 6\end{array}$ & $\begin{array}{l}19 \cdot 9 \\
12 \cdot 2\end{array}$ & $\begin{array}{l}62 \cdot 7 \\
11 \cdot 6\end{array}$ \\
\hline \multirow{2}{*}{\multicolumn{7}{|c|}{$\mathrm{FEV}_{1}$ as $\%$ of FVC }} \\
\hline $\begin{array}{l}\text { (mean) } \\
(\mathrm{SD})\end{array}$ & $81 \cdot 8$ & $83 \cdot 0$ & & & & \\
\hline (SD) & $12 \cdot 6$ & $12 \cdot 0$ & $10 \cdot 3$ & $14 \cdot 8$ & $11 \cdot 1$ & $13 \cdot 7$ \\
\hline \multicolumn{7}{|l|}{ Circulatory system } \\
\hline $\begin{array}{l}\text { Pulse rate (mean) } \\
\text { (SD) }\end{array}$ & $\begin{array}{l}70 \cdot 3 \\
10 \cdot 8\end{array}$ & $\begin{array}{l}75 \cdot 9^{\star \star \star} \\
9 \cdot 3^{-1}\end{array}$ & $\begin{array}{l}72 \cdot 7 \\
10 \cdot 1\end{array}$ & $\begin{array}{l}78 \cdot 2^{\star \star \star} \\
9 \cdot 1\end{array}$ & $\begin{array}{l}71 \cdot 6 \\
10 \cdot 5\end{array}$ & $\begin{array}{l}77 \cdot 0^{\star \star \star} \\
9 \cdot 2\end{array}$ \\
\hline \multicolumn{7}{|l|}{ Systolic Pressurc } \\
\hline $\begin{array}{l}\text { (mean, mmHg) } \\
\text { (SD) }\end{array}$ & $124 \cdot 5$ & $123 \cdot 8$ & $115 \cdot 3$ & $111 \cdot 3$ & $119 \cdot 4$ & $117 \cdot 9$ \\
\hline $\begin{array}{c}\text { (SD) } \\
\text { Diastolic Pressure }\end{array}$ & $15 \cdot 1$ & $19 \cdot 6$ & $14 \cdot 9$ & $12 \cdot 8$ & $15 \cdot 6$ & $17 \cdot 8$ \\
\hline \multicolumn{4}{|l|}{ Diastolic Pressure } & & & $80 \cdot 7^{\star \star}$ \\
\hline (SD) & $11 \cdot 9$ & $13 \cdot 3$ & $11 \cdot 3$ & $10 \cdot 1$ & $12 \cdot 0$ & $13 \cdot 3$ \\
\hline No of cases (unweighted) & 141 & 75 & 178 & 84 & 319 & 159 \\
\hline
\end{tabular}

${ }^{\star} \mathrm{p}<0.05^{\star \star} \mathrm{p}<0.01^{\star \star \star} \mathrm{p}<0.001$
$\mathrm{FEV}_{1}=$ forced expiratory volume in one second; FVC=forced vital capacity. ation rather than that in Glasgow, where Muslims predominate.

\section{ANALYSIS}

For brevity, tabulations show ranked health variables using a single cutting point, but significance tests take into account all the ranked categories on each variable. Unless otherwise stated, the statistics used are Kendall's tau b, or for normally distributed continuous health variables, analysis of variance.

\section{Results}

The sample of South Asian descent was relatively homogeneous. Eighty six per cent were Punjabi speakers (equally divided between Muslims and non-Muslims (mainly Sikhs)), $89 \%$ had been born in the Indian subcontinent and most of the others had been born in Scotland or East Africa. Those born abroad had arrived in the UK between 1950 and 1986, with mean 1970 . Most $(88 \%)$ were owner-occupiers (against $55 \%$ in the general population sample). Half the men and $45 \%$ of the women had $\mathrm{O}$ level grades or had matriculated in secondary school subjects in the subcontinent. Fourteen per cent of the men were unemployed and of those in work over half $(55 \%)$ were self employed. Of the remainder, $60 \%$ were in manual employment and $24 \%$ in social classes I and II. The main sectors of employment included retail, catering, transport, and paramedical work. In the general population sample $46 \%$ of men in work were in manual occupations.

In the South Asian sample, social differentiation, apart from that by gender which is reported here, was thus principally by socioeconomic class and religion. Conventional social class measures are not satisfactory for a population with such high rates of self employment, and alternative measures to assess the influence of socioeconomic position will be discussed elsewhere. Religion was associated with none of the physical measures, and only with very few self report measures other than symptoms, where Muslims reported more symptoms than non-Muslims.

Tables I-IV compare the health of the general population of Glasgow with those of South Asian origin, by sex. For brevity, comparative statements by sex (eg 'more men') always refer, unless otherwise indicated, to South Asians of that sex in comparison with the general population of the same sex, not to comparisons between men and women.

Table I shows indices of overall physical development. South Asians were much shorter and broader in the waist and hip, and the women had a greater body mass and a higher waist/hip ratio. These results are not accounted for by differences in the amount of clothing. Among both sexes, standardised FVC and standardised $\mathrm{FEV}_{1}$ were much smaller, but $\mathrm{FEV}_{1}$ as a percentage of FVC was not different. Finally, the pulse rate of South Asians was higher and the men had a higher diastolic blood pressure, these results being unaccounted for by room temperature, by whether the respondent had smoked or taken exercise that day, or by current illness. The distributions of $\mathrm{FEV}_{1}$ and blood pressure data among South Asians and the general population 
were similarly shaped, and in both populations blood pressure was similarly related to body mass, and $\mathrm{FEV}_{1}$ to height. It is relevant that South Asians were less likely than the general population to be current or past smokers (especially nonMuslims and women), and less likely ever to have drunk alcohol (especially Muslims and women).

Table II shows a range of morbidity indicators. More South Asians of both sexes were mildly overweight compared with the general population, and more women were seriously so. With regard to measures of respiratory illness, fewer of the South Asian men said they had brought up phlegm on most days for three months of the year, but more of the women had low $\mathrm{FEV}_{1}$ in relation to their vital capacity, and in reports of the chronic conditions noted in Table IV more said they had had asthma, nearly all of whom were being treated currently. More South Asian women had angina or possible myocardial infarction. High blood pressure was

Table II Morbidity indicators at age 30-40 years in South Asians compared with the general population in Glasgow, by sex

\begin{tabular}{|c|c|c|c|c|c|c|}
\hline \multirow[b]{2}{*}{$\begin{array}{l}\text { Morbidity } \\
\text { indicators }\end{array}$} & \multicolumn{2}{|l|}{ Men } & \multicolumn{2}{|l|}{ Women } & \multicolumn{2}{|l|}{ All } \\
\hline & $\begin{array}{l}\text { General } \\
\text { population }\end{array}$ & $\begin{array}{l}\text { South } \\
\text { Asians }\end{array}$ & $\begin{array}{l}\text { General } \\
\text { population }\end{array}$ & $\begin{array}{l}\text { South } \\
\text { Asians }\end{array}$ & $\begin{array}{l}\text { General } \\
\text { population }\end{array}$ & $\begin{array}{l}\text { South } \\
\text { Asians }\end{array}$ \\
\hline $\begin{array}{l}\text { Body structure } \\
\text { Overweight: mildly (\%) } \\
\text { seriously (\%) }\end{array}$ & $\begin{array}{r}36 \\
9\end{array}$ & $\begin{array}{r}50 \\
6\end{array}$ & $\begin{array}{l}22 \\
19\end{array}$ & $\begin{array}{l}38 \\
27^{\star \star}\end{array}$ & $\begin{array}{l}28 \\
15\end{array}$ & $\begin{array}{l}44 \\
16^{\star \star}\end{array}$ \\
\hline $\begin{array}{l}\text { Respiratory system } \\
\text { FEV } 1 \text { FVC below mean: } \\
1 \text { SD (\%) } \\
2 \text { SD (\%) } \\
3 \text { months' phlegm }(\%)\end{array}$ & $\begin{array}{r}6 \\
4 \\
13\end{array}$ & $\begin{array}{l}6 \\
4 \\
4^{\star}\end{array}$ & $\begin{array}{r}7 \\
2 \\
12\end{array}$ & $\begin{array}{l}12 \\
8^{\star} \\
8\end{array}$ & $\begin{array}{r}7 \\
3 \\
13\end{array}$ & $\begin{array}{l}9 \\
6 \\
6\end{array}$ \\
\hline $\begin{array}{l}\text { Circulatory sustem } \\
\text { Blood pressure } \\
\geq 160 / 95 \mathrm{mmHg}(\%) \\
\text { Angina or possible myo- } \\
\text { cardial infarction (\%) }\end{array}$ & $\begin{array}{r}14 \\
9\end{array}$ & 22 & 6 & $14^{\star}$ & 9 & $\begin{array}{c}14^{\star} \\
9\end{array}$ \\
\hline $\begin{array}{l}\text { Mental health } \\
\text { GHQ, 3+ items } \\
\text { endorsed (\%) } \\
\text { GHQ, 4+ items } \\
\text { endorsed (\%) }\end{array}$ & 19 & 12 & 24 & 16 & 22 & $14^{\star}$ \\
\hline No of cases (unweighted) & 141 & 75 & 178 & 84 & 319 & 159 \\
\hline
\end{tabular}

Table III Experience of symptoms at age 30-40 years in South Asians compared with the general population in Glasgow, by sex

\begin{tabular}{|c|c|c|c|c|c|c|}
\hline \multirow[b]{2}{*}{ Symptoms } & \multicolumn{2}{|l|}{ Men } & \multicolumn{2}{|l|}{ Women } & \multicolumn{2}{|l|}{ All } \\
\hline & $\begin{array}{l}\text { General } \\
\text { population }\end{array}$ & $\begin{array}{l}\text { South } \\
\text { Asians }\end{array}$ & $\begin{array}{l}\text { General } \\
\text { population }\end{array}$ & $\begin{array}{l}\text { South } \\
\text { Asians }\end{array}$ & $\begin{array}{l}\text { General } \\
\text { population }\end{array}$ & $\begin{array}{l}\text { South } \\
\text { Asiuns }\end{array}$ \\
\hline \multicolumn{7}{|l|}{ Total no } \\
\hline Tend to have $(\% 6+)$ & 27 & 26 & 30 & 42 & 30 & 36 \\
\hline Had last month $(\% 6+)$ & 21 & $13^{\star}$ & 22 & $42^{\star \star}$ & 21 & 27 \\
\hline \multicolumn{7}{|l|}{ Respiratory } \\
\hline Tend to have ( $\%$ any) & 49 & 51 & 49 & 66 & 49 & 58 \\
\hline Had last month ( $\%$ any) & 46 & $32^{\star}$ & 41 & 52 & 43 & 41 \\
\hline \multicolumn{7}{|l|}{ Digestive } \\
\hline Tend to have ( $\%$ any) & 43 & $22^{\star \star}$ & 43 & 45 & 43 & $33^{\star}$ \\
\hline Had last month ( $\%$ any) & 34 & $10^{\star \star \star}$ & 42 & 44 & 38 & $26^{\star}$ \\
\hline \multicolumn{7}{|l|}{ Musculoskeletal } \\
\hline Tend to have ( $\%$ any) & 36 & $21^{\star}$ & 31 & 32 & 33 & 26 \\
\hline Had last month ( $\%$ any) & 31 & $14^{\star}$ & 26 & 35 & 28 & 24 \\
\hline \multicolumn{7}{|l|}{ Psychosomatic } \\
\hline \multirow{2}{*}{$\begin{array}{l}\text { Tend to have (1\% } 5+) \\
\text { Had last month }(\% 5+)\end{array}$} & 15 & 10 & 17 & $36^{\star \star}$ & 16 & 23 \\
\hline & 12 & 7 & 17 & $36^{\star \star}$ & 15 & 21 \\
\hline \multicolumn{7}{|l|}{ Other } \\
\hline Tend to have ( $\%$ any) & 30 & 24 & 38 & 33 & 34 & 28 \\
\hline Had last month (\% any) & 28 & 20 & 28 & 25 & 28 & 22 \\
\hline No of cases (unweighted) & 141 & 75 & 178 & 84 & 319 & 159 \\
\hline
\end{tabular}

more common in South Asians as a whole, the difference being contributed by the men, and in reports of the chronic conditions noted in table IV more of the men said they had diabetes. There were no differences, however, in the proportions of either sex that showed possible clinical levels of psychiatric response on the GHQ, and for both sexes together the proportion of South Asians with such responses was smaller.

Tables III and IV show measures of reported health. Before looking at these tables, it should be noted that symptom reports have a subjective element and have been found to be related to psychological distress, a finding confirmed in the present data by a strongly significant relation between the number of symptoms reported and potentially clinical levels of response on the General Health Questionnaire. The strength of the relationship, however, was closely similar for South Asians and for the general population. On the other hand, the number of chronic conditions and accidents (item in Table IV) were not related to the GHQ in either group.

Table III details groups of symptoms which respondents said that they tended to experience, or had experienced in the last month. Fewer men of South Asian descent mentioned symptoms than their counterparts in the general population, whether overall or in the respiratory, digestive, or musculoskeletal subgroups. More of the South Asian women, however, had experienced five or more psychosomatic symptoms than their counterparts, both as a tendency and in the last month, and more had experienced six or more symptoms of all kinds. Symptom reports were noticeably more frequent among South Asian women than among South Asian men.

Table IV shows the findings in respect of chronic conditions and sickness behaviour. More South Asians said they had a full set of teeth, and fewer had glasses (not significant among women) or hearing problems (not significant among men). Many fewer of both sexes mentioned accidents since age 15 years, and many fewer men mentioned them at work. With regard to more general medical conditions, fewer South Asian men reported a longstanding illness in response to an open ended question. Nevertheless, they were not dissimilar in their responses to our prompt list of chronic conditions, and the women mentioned more chronic conditions than women in general. The sickness behaviour of South Asians was complex and did not correspond closely to these differences in medical problems. Fewer South Asian men said they had taken time off work in the last year because of illness, but much the same proportion as among men in general mentioned time spent ill in bed, and actually more had taken over two weeks off work or in bed in total. These results illustrate an interesting finding-compared with the general population, the number of days taken off work or spent ill in bed by South Asian men and women tended to extremes, either none at all (especially among the self employed) or exceeding a week or, more usually, two weeks in total. The differences in these instances are significant ( $x^{2}$ test). The only exception is among women at work, where South Asian numbers were small. 


\section{Discussion}

The aim of the analysis was not to establish the prevalence of diagnosed conditions or to detect all medically significant differences between South Asians and the general population. The study design focused on health conditions commonly experienced by people in their 30 s that have implications for health later in life, and the sample size is capable of detecting differences of an order known to occur reasonably frequently between the two groups concerned; but the existence of smaller or rarer differences is not ruled out. In addition, with a fair number of measures being considered, isolated results at the $5 \%$ level of significance should be interpreted carefully.

Thus, the aim has been to assess the balance of significant health differences, positive $v$ negative, between South Asians and the general population according to sex, requiring that sufficient significant observations should be made across a sufficiently broad spectrum for the purpose of the assessment. Although in the nature of the topic not complete, the range of measures, running from anthropometric measures through indicators of common morbidity and symptomatology to chronic conditions and sickness behaviour, is much broader than hitherto attempted and a little under half of these showed significant differences.

A comparison of population groups of different cultural origin is subject to a number of initial cautions. We note three in particular.

Firstly, translation is not an exact science, because the cultural context associated with apparently similar words inevitably differs in subtle respects. Our use of written and previously piloted translations should have minimised this risk, but data on symptoms are very prone to translation problems. This obviously applied to the symptoms in table III, but the angina and GHQ findings in table II also fall into this

Table IV Experience of chronic conditions, accidents, and sickness behaviour at age 30-40 years in South Asians compared with the general population in Glasgow, by sex

\begin{tabular}{|c|c|c|c|c|c|c|}
\hline \multirow[b]{2}{*}{$\begin{array}{l}\text { Chronic conditions, accidents, } \\
\text { and sickness behaviour }\end{array}$} & \multicolumn{2}{|l|}{ Men } & \multicolumn{2}{|l|}{ Women } & \multicolumn{2}{|l|}{ All } \\
\hline & $\begin{array}{l}\text { General } \\
\text { population }\end{array}$ & $\begin{array}{l}\text { South } \\
\text { Asians }\end{array}$ & $\begin{array}{l}\text { General } \\
\text { population }\end{array}$ & $\begin{array}{l}\text { South } \\
\text { Asians }\end{array}$ & $\begin{array}{l}\text { General } \\
\text { population }\end{array}$ & $\begin{array}{l}\text { South } \\
\text { Asians }\end{array}$ \\
\hline & \\
\hline $\begin{array}{l}\text { no problems, but } \\
\text { glasses (\%) }\end{array}$ & 40 & $21^{\star \star}$ & 50 & 34 & 45 & $27^{\star \star \star}$ \\
\hline $\begin{array}{l}\text { Problems with } \\
\text { hearing (\%) } \\
\text { Lost } 1+\text { teeth (\%) }\end{array}$ & $\begin{array}{l}13 \\
88\end{array}$ & $7^{7}$ & $\begin{array}{l}10 \\
86\end{array}$ & $\begin{array}{l}2^{\star} \\
70^{\star \star \star}\end{array}$ & $\begin{array}{l}11 \\
87\end{array}$ & $\begin{array}{l}4^{\star} \\
54^{\star \star \star}\end{array}$ \\
\hline \multicolumn{7}{|l|}{ Medical } \\
\hline $\begin{array}{l}\text { Limiting longstanding } \\
\text { illness (\%) } \\
\text { t+ of } 11 \text { chronic }\end{array}$ & 23 & 14 & 22 & 17 & 22 & 16 \\
\hline $\begin{array}{l}1+\text { of } 11 \text { chronic } \\
\text { conditions }(\%)\end{array}$ & 26 & 21 & 21 & $36^{\star}$ & 23 & 28 \\
\hline $\begin{array}{l}\text { Accidents } \\
\text { At work, ever (\%) } \\
\text { Any, since age } 15(\%)\end{array}$ & $\begin{array}{l}51 \\
78\end{array}$ & $\begin{array}{l}19^{\star \star \star} \\
36^{\star \star \star}\end{array}$ & $\begin{array}{l}14 \\
51\end{array}$ & $\begin{array}{l}12 \\
20^{\star \star \star}\end{array}$ & $\begin{array}{l}31 \\
64\end{array}$ & $\begin{array}{l}16^{\star \star \star} \\
29^{\star \star \star}\end{array}$ \\
\hline \multicolumn{6}{|l|}{$\begin{array}{l}\text { Sickness behaviour } \\
\text { Off work last year: } \\
\text { One or }\end{array}$} & 42 \\
\hline $\begin{array}{l}\text { Total over } 14 \text { days } \\
\text { (\% of those in work) }\end{array}$ & 8 & $18^{\star}$ & 11 & 9 & 10 & 16 \\
\hline $\begin{array}{l}\text { In bed last year: } \\
\text { One or more times }(\%) \\
\text { Total over } 14 \text { days }(\%)\end{array}$ & $\begin{array}{r}50 \\
4\end{array}$ & $\begin{array}{l}42 \\
14^{\star}\end{array}$ & $\begin{array}{r}56 \\
6\end{array}$ & $\begin{array}{l}47 \\
11^{\star \star}\end{array}$ & $\begin{array}{r}53 \\
5\end{array}$ & $\begin{array}{l}45 \\
12^{\star \star \star}\end{array}$ \\
\hline No of cases (unweighted) & 141 & 75 & 178 & 84 & 319 & 159 \\
\hline
\end{tabular}

${ }^{\star} \mathrm{p}<0.05{ }^{\star \star} \mathrm{p}<0.01{ }^{\star \star \star} \mathrm{p}<0.001$ category, and questions about their translation have been raised elsewhere. ${ }^{27} 28$ Results on the angina questionnaire show that a high proportion of South Asian women were positive for angina or possible myocardial infarction but other studies have also shown high rates of positive response among women of this age group, with fair reliability over time. It has been argued that these results indicate a genuine symptom pattern which is, however, less specific for atherosclerotic coronary heart disease. ${ }^{29}$ Our GHQ results also seem to have some validity, for reasons discussed in the next paragraph. And translation problems are unlikely to account for the striking differences between South Asian men and women which are such a feature of the symptom reports.

Secondly different cultural norms and experience of medical services may mean different thresholds for reporting, whether to interviewers or to doctors, and variable compliance with physical measures. The self report measures in tables III and IV are again relevant here, and certainly it seems that the General Household Survey questions on longstanding illness in table IV may have been reported differently by South Asians and by the population as a whole. The open question on longstanding illness and the independent question on chronic conditions elicited similar responses among South Asians, while in the general population the open question elicited more responses, suggesting that South Asian responses to the questions on longstanding illness were conservative. In the predictable relation between number of symptoms reported and responses on the GHQ, however, it is reassuring to find a close similarity between South Asians and the general population, and to find in both groups that the GHQ and the number of chronic conditions and accidents reported are unrelated.

In physical investigations, nervousness may cause an increase in blood pressure and pulse rate, and lung function measurements require a cooperative zeal that may seem more absurd in some cultures than in others. Here, it is again reassuring that the distributions of $\mathrm{FEV}_{1}$ and blood pressure and their predictable relation to height were similar among South Asians and the general population.

Thirdly physiological norms may differ. As noted below, the measures of lung function in table I afford a prime example. The lungs of South Asians are smaller, and so $\mathrm{FEV}_{1}$ and vital capacity standardised for height is lower: hence the only directly comparable health measure is the percentage of $\mathrm{FEV}_{1}$ over FVC.

Bearing these cautions in mind, we can now attempt to answer the first question we posed in the introduction-how healthy is the South Asian community compared with the general population? The answer to this question is complex. In many ways the results on health were comparable. Indeed there were no statistically significant differences for a little over half of the measures we report, and for the remainder South Asians were in better health in some respects and worse in others.

The most striking differences were in physical development. South Asians were shorter, the women were more likely to be overweight, and both sexes had evidence of central deposition of fat (overall mean difference in waist size was $6.5 \mathrm{~cm}$ ). 
Central deposition of fat has recently been reported in South Asians by McKeigue et al. ${ }^{30}$ It is probable that the height differential is not solely genetic and reflects environmental deprivation in childhood, a potentially important risk factor for disease, including cardiovascular disease. ${ }^{31}$

The high cardiovascular mortality and hospital admission rates of South Asians, which still pose problems of explanation, may be related both to these factors and to the findings on blood pressure. The mean diastolic blood pressure of South Asian men, and the prevalence of hypertension (NS by sex), were higher than in the general population, a finding similar to that of McKeigue et al, ${ }^{30}$ but in contrast to other studies. ${ }^{32} 33$

Mortality from respiratory disease is below average in South Asian men, but marginally above average among the women, 920 and hospital admissions for asthma are high, although no basis for this has so far been found in excess morbidity. ${ }^{34-36}$ In the present study, as elsewhere, the lungs of South Asian men and women were found to be substantially smaller than in the general population. These differences are probably genetic, though environmental factors may also be important. ${ }^{37}$ Although the respiratory health of men in the South Asian sample was slightly better than in the general population, the findings for women were more problematic. Women were more likely to have an $\mathrm{FEV}_{1} / \mathrm{FVC}$ ratio that was $2 \mathrm{SDs}$ or more below the mean (reflected in the mean $\mathrm{FEV}_{1} / \mathrm{FVC}$ ), to report asthma among their chronic conditions, and to report respiratory symptoms (NS).

In self reporting on problems with sight, hearing, loss of teeth, and accidents South Asian men and women were generally in better health. In their experience of symptoms, both in terms of a general tendency, and specifically in the previous month, South Asian men were generally in better health. Women, however, were more likely to report symptoms, and this was particularly notable for symptoms which cluster on a psychosomatic dimension.

The issue of the mental health status of South Asian populations is controversial. ${ }^{17}$ Studies of hospital admission rates are conflicting, ${ }^{38} 39$ and one national study has found a high suicide rate among women. ${ }^{9}$ Two community surveys of psychological symptoms (Langner scale) have found less distress among South Asians than among native English. ${ }^{4041}$ It has been suggested that conflicting evidence on mental health may well be a result of the variable extent to which somatic dimensions of distress are recognised and recorded..$^{42}$ Our data tend to support this. On the basis of the GHQ the psychological distress of South Asians is no greater, and possibly less, than that of the general population. But this reassuring finding is at odds with the high proportion of women with psychosomatic symptoms. The findings support the hypothesis that South Asians, in this instance, women, may in some sense 'somatise' mental health problems, though this issue needs deeper analysis. ${ }^{43}$

The final perspective on health status is provided by the data on long standing illness and sickness behaviour. South Asian men seemed to be in a comparatively good position on these measures. They reported less long standing illness and they were off work less often than the general population. In this last respect, this extensively self employed population differed from the South Asian factory workers described by Baker and Pocock, ${ }^{44}$ though there was also a larger subgroup among them than in the general population who were off work and in bed for long periods. Women fared less well, mentioning more chronic conditions than Glaswegian women in general and again there was a relatively large subgroup who were ill in bed for long periods.

Overall, the differences, where they occur, between the South Asian and the general population of Glasgow tend to balance out, except in the anthropometric measures. This does conceal a substantial difference between the results for men and women, however, for while South Asian men had a number of advantages over Glaswegian men as a whole, the women had a concentration of disadvantages compared with women as a whole. While in the general population the health measures of men and women showed expected differences, these differences are dwarfed by the gap between South Asian men and women, particularly in regard to symptoms, chronic conditions and sickness behaviour. We hope to return to this subject in a future paper.

Does the fact that the comparison is with the Glasgow population affect the conclusions which can be drawn about the health of South Asians? Glasgow has an unenviable reputation for poor health and the comparison, though by no means flattering to the South Asian population, may have led to a false optimism. Comparing these data with the national Health and Lifestyle Survey, ${ }^{18}$ we find that the Glasgow population is shorter, has more obesity (and central obesity), has higher diastolic blood pressure, and reports more symptoms than the national average. In comparison with the national figures, therefore, the Glasgow South Asians, both men and women, would have more disadvantages and fewer advantages.

Three main conclusions emerge from these data. Firstly, the common experience of health of South Asians in their 30 s is not straightforwardly worse than that of the general population; the picture is complex, except in regard to anthropometric measures. Secondly, while South Asian men have a number of health advantages over Glaswegians in general, the women suffer a concentration of disadvantages and the gap between men and women is apparently greater among South Asians. Thirdly, our findings indicate patterns of health at age $30-40$ years which shed light on the documented pattern of hospital admission and mortality, especially in regard to cardiovascular and respiratory conditions, and they also show a complex pattern of psychological health which may help to interpret the equally complex pattern of psychiatric admissions.

We are grateful to our interviewers and nurses; to Sheila Bhatt, Russell Ecob, and Graham Watt for their advice; to Guy Muhlemann, Carol Nicol, Lindsay Macaulay, and Patricia Fisher for help with data cleaning and computing; and to Jacqui Irwin, who helped with the typing. We also acknowledge helpful suggestions from a referee. 
1 Haskey F. The ethnic minority populations resident in private of England and Wales. Population Trends 1991; 63: 22-35.

2 Shaunak S, Lakhani SR, Abraham S, Maxwell JD. Differences among Asian patients. BMF 1986; 293: 1169 .

3 Henley A. Asian patients in hospital and at home. London: King's Fund, 1979.

4 Bhopal RS. Future research on the health of ethnic minorities: back to basics-a personal view. Ethnic Minorities Health 1990; 1 (3): 1-3.

. Johnson MRD. Ethnic minorities and health. Foumal of the Johnol MRD. Ethnic minorities and health. Fournal of the Royal College of Physicians. (London) 1984, 18: 228-30.

Ahmad WIU. Policies, pills and political will: a critique of policies to improve the

7 Donaldson LJ, Clayton DG. Occurrence of cancer in Asians and non-Asians. F Epidemiol Community Health 1984; 38 203-7.

8 Balarajan R, Adelstein AM, Bulusu L, Shukla V. Patterns of mortality among migrants to England and Wales from the Indian subcontinent. BMF 1984; 289: 1185-7.

9 Marmot MG, Adelstein AM, Bulusu L. Immigrant mortality in England and Wales 1970-78. London: HMSO, 1984

10 Fox AJ, Goldblatt PO. Longitudinal study 1971-1975: sociodemographic mortality differentials. London: HMSO, 1982.

11 Ramaiya KL, Swai ABM, McLarty DG, Bhopal RS, Alberti KGMM. Differences in diabetes and coronary risk factors in Hindu Indian subcommunities in Tanzania. BMF 1991 303; 271-6.

12 Donovan JL. Ethnicity and health: a research overview. Soc Sci Med 1984; 19: 663-70.

13 Medical Research Council Tuberculosis and Chest Diseases Unit. National survey of notifications of tuberculosis in England and Wales in 1983. BMF 1985; 291: 658-61.

14 Peach H. A critique of survey methods used to measure the occurrence of osteomalacia and rickets in the United Kingdom. Community Medicine 1984; 6: 20-8.

15 Ramaiya KL, Kodali VRR, Alberti KGMM. Epidemiology of diabetes in Asians of the Indian subcontinent. Diabetes Metabolism Reviews 1992; 6: 125-46.

16 McKeigue PM, Miller GH, Marmot MG. Coronary hear disease in South Asians overseas: a review. 7 Clin Epidemio 1989; 42: 597-609.

17 Ineichen B. The mental health of Asians in Britain. BMf 1990; 300: $1669-70$

18 Cox BD, Blaxter M, Buckle ALJ, et al. The health and lifestyle survey. London: Health Promotion Trust, 1987.

19 Ecob R, Williams R Sampling Asian minorities to assess health and welfare. $\mathcal{F}$ Epidemiol Community Health 1991; 45 : 93-101.

20 Balarajan R, Bulusu L. Mortality among immigrants in England and Wales. In: Britton $\mathrm{M}$ ed. Mortality and England and Wales. In: Britton

21 Rose GA. The diagnosis of ischaemic heart pain and intermittent claudication in field surveys. Bull World Health Organ 1962; 27: 645-58.

22 Florey C du V, Leeder SR. Methods for cohort studies of chronic airflow limitation. Copenhagen: World Health Organization, 1982

23 Goldberg DP. The detection of psychiatric illness by questionnaire. Oxford: Oxford University Press, 1972.
24 Dressler WW. Psychosomatic symptoms, stress and modernisation: a model. Culture, Medicine and Psychiatry 1985; 9: 257-86.

25 Royal College of Physicians London. Obesity. Journal of the Royal College of Physicians 1983; 17: 5-65.

26 Fletcher C, Peto R, Tinker C, Speizer FE. The natural history of chronic bronchitis and emphysema. Oxford: Oxford University Press, 1976 appendix B.6.

27 Rose G, McCartney P, Reid DD. Self-administration of a questionnaire on chest pain and intermittent claudication.

28 Currer C. Concepts of mental well- and ill-being: the case of Pathan mothers in Britain. In: Currer C, Stacey $M$ eds. Concepts of health, illness and disease. Leamington: Berg, 1986.

29 Harris RB, Weissfeld LA. Gender differences in the reliability of reporting symptoms of angina pectoris. $\mathcal{F}$ Clin

30 McKeigue PM, Shah B, Marmot MG. Relation of central obesity and insulin resistance with high diabetes prevalence and cardiovascular risk in South Asians. Lancet 1991; 337 382-6.

31 Barker DJP. The foetal and infant origins of inequalities in health in Britain. F Public Health Med 1991; 13: 64-68.

32 McKeigue PM, Marmot MG, Syndercombe Court YD, Cottier DE, Rahman S, Riemersma RA. Diabetes, hyperinsulaemia and coronary risk factors in Bangladeshis in East London. Br Heart F 1988; 60: 390-6.

33 Cruickshank JK, Jackson SHD, Beevers DG, Bannan LT, Beevers M, Stewart VL. Similarity of blood pressures of blacks, whites and Asians in England. $\mathcal{F}$ Hypertension 1985; 3: $365-71$.

34 Jackson SHD, Bannan LT, Beevers DG. Ethnic differences in respiratory disease. Postgrad Med f 1981; 57: 777-8.

35 Desian L Taylor JB. Patterns of Asian and non-Asian morbidity in hospital. BMF 1983; 286: 949-51.

36 Sturman S, Bovers DG. General medical problems. In McAvoy BR, Donaldson LJ, eds. Health care for Asians. Oxford: Oxford University Press, 1990.

37 Mathur N, Rastogi SK, Gupta BN, Husain T. A globa comparison of predicting equations on spirometry in the male population. Int $\mathcal{F}$ Epidemiol 1990; 19: 331-7.

38 Rack P. Psychological and psychiatric disorders. In: McAvo BR, Donaldson LJ, eds. Health care for Asians. Oxford: Oxford University Press, 1990

39 Cochrane R, Bal SS. Mental hospital admission rates of immigrants to England: a comparison of 1971 and 1981 . Social Psychiatry and Psychiatric Epidemiology 1989; 24 2-11.

40 Cochrane R, Stopes-Roe M. Psychological and social adjustment of Asian immigrants to Britain: a community survey. Social Psychiatry 1977; 12: 195-206.

41 Cochrane R, Stopes-Roe M. Psychological symptom levels in Indian immigrants to England-a comparison with native in Indian immigrants to England-a compar

42 Leff J. Psychiatry around the globe. 2nd ed. Londor: Gaskell, 1988.

43 Fenton S, Poonia K GP consultations, concepts of illness: South Asians in Bristol. Swindon: ESRC Research Report, 1988.

44 Baker CC. Pocock SJ. Ethnic differences in certified sickness absence. Br f Ind Med 1982; 39: 277-82. 